Portland State University

PDXScholar

Urban Studies and Planning Faculty

Nohad A. Toulan School of Urban Studies and

Publications and Presentations

Planning

Summer 1996

\title{
Science in Environmental Conflicts
}

Connie P. Ozawa

Portland State University, ozawac@pdx.edu

Follow this and additional works at: https://pdxscholar.library.pdx.edu/usp_fac

Part of the Social and Behavioral Sciences Commons

Let us know how access to this document benefits you.

\section{Citation Details}

Ozawa, C. P. (1996). SCIENCE IN ENVIRONMENTAL CONFLICTS. Sociological Perspectives, 39(2), 219-230.

This Article is brought to you for free and open access. It has been accepted for inclusion in Urban Studies and Planning Faculty Publications and Presentations by an authorized administrator of PDXScholar. Please contact us if we can make this document more accessible: pdxscholar@pdx.edu. 


\title{
SCIENCE IN ENVIRONMENTAL CONFLICTS
}

\author{
CONNIE P. OZAWA* \\ Portland State University
}

\begin{abstract}
Science plays a major part in environmental conflict. How that role is defined is determined by the human actors engaged in the conflict and the legal and institutional constructs that structure discourse. This article begins by tracing the authority invested in science to ideological assumptions about scientific methodology. Then, four common roles for science in environmental conflict (discoverer, mechanism of accountability, shield, and toal of persuasion), are described. These roles are increasingly unproductive in resolving environmental conflict, partly due to the misfit between the actual conduct of science and its ideal. This article proposes that a new role, one that is more consistent with a social constructionist view of science, has been crafted as a byproduct of decision-making innovations that prescribe explicit negotiations among representatives of groups engaged in an environmental dispute. As a tool of facilitation, science may be used more constructively to resolve environmental disputes.
\end{abstract}

\section{INTRODUCTION}

The April 20, 1993, New York Times reported another environmental controversy (Strum 1993). The Port Authority of New York and New Jersey filed an application to the U.S. Army Corps of Engineers to dredge container-ship berths in Newark Bay and dump the dredged material in the ocean. What had been an annual rite met delay when routine analysis of the silt to be displaced was found to contain dioxin. Two groups, environmentalists concerned about the impact of dioxin on marine life, such as endangered whales and sea turtles, and the coastal tourism industry, advocated storing the dredged material on containment islands or barges until economical and effective decontamination technologies became available. Although ultimately resolved, more than three years later the Port

"Direct all correspondence to: Connie P. Ozawa, Portland State University, Department of Urban Studies and Planning, Portland, OR 97207. 
Authority was still waiting for permit approval, losing revenues from nearly half the harbor's prime container ship berths.

Action on the application was delayed for a number of reasons. First, because no federal standards existed for dioxin contamination in the ocean, the EPA regional office attempted to establish acceptable levels for this case. The threshold for contamination initially set by EPA was later modified, requiring more testing, resulting in further delay, and fueling debate over testing methods. Second, although the U.S. Army Corps of Engineers had conducted research on safe methods of ocean disposal, no research specifically on the dumping of dioxin had been performed and environmentalists raised doubt about the ability to prevent the spread of dioxin-contaminated silt across the ocean floor. Finally, technological advances during the 36-month delay led to continual refinement of the scientific data on which regulators, environmentalists, and the port were basing their decisions. Rather than engendering greater confidence in the numbers, such modifications had the contrary effect of increasing skepticism about the effectiveness and stability of the government standard. If the numbers were revised once, what would prevent subsequent reconsideration?

Though the heat underlying the conflict over the harbor dredging was generated by the ethical, economic, and ideological implications of alternative actions, much of the public debate focused on the technical issues of standards, criteria, and testing methodologies. This dispute illustrates what has become a common role of science in environmental conflict-science used as a weapon in the arsenal of warring public policy actors.

Environmental conflict was a term virtually unheard of before the 1960s. Thirty years later, it is used commonly to refer to the numerous contests over the allocation of natural resources, pollution control, and land use. What once were mundane activities, such as logging, road building, or dredging harbor floors, now frequently provoke raging disputes among contenders equally likely to claim to be the protectors of environmental quality. In this article, a distinction is made between the terms "dispute" and "conflict." Dispute refers to vocalized or articulated disagreements over what ought to be done. Conflict is the underlying basis for the disagreement-the perceptions (accurate or not) of an undesirable distribution of consequent costs and benefits and/or the more subtle redistribution of political control over similar decisions in the future.

Environmental disputes arise not only from the perceptions of unfavorable, potential consequences of proposed actions, but also the sense of the legal rights and recourse awarded individuals and groups, and validated and institutionalized in national legislation in the United States. Federal legislation, starting earlier but most exemplified by the National Environmental Policy Act (1969), mandate that decisions affecting the environment ensure that adverse impacts are mitigated to the fullest extent possible. What is adverse, of course, is subject to interpretation, but clearly the presumption of NEPA is that impacts can be identified and evaluated prior to actual implementation of a proposed action. The Clean Air Act instructs the Environmental Protection Agency to issue air quality criteria that "accurately reflect the latest scientific knowledge useful in indicating the kind and extent of all identifiable effects on public health and welfare" (Clean Air 
Act 1967). Importantly, these laws and many others include citizen suit provisions that explicitly award citizens the legal right to question government actions.

Legislation like these have set the stage for decision makers and others to spotlight the scientific and technical elements in environmental disputes. Rather than having a role of equal standing with the human actors in a conflict, however, science ought best be viewed as a prop in the hands of those enacting environmental conflicts. This article is about the multiple ways science is used in environmental conflict. In addition to identifying and describing these multiple roles, I argue that a traditional image of science is essential in order for science to be used in these ways. I also describe an emerging alternative role, one that is more consistent with the social constructionist image of science. Before examining the various purposes for which this prop called science is used, let us first proceed through a brief review of how science became so central in environmental conflict.

\section{THE AUTHORITY OF SCIENCE}

In the economic and cultural context of the later 20th century United States and, indeed, in much of the industrialized world, science is looked upon as a source of authority. This authority derives from a popular notion of the scientific endeavor. Science is conceived as a process that yields an objective, rational, politically neutral body of knowledge. Decisions consistent with scientific knowledge, therefore, command acceptance.

A principal feature of the popular conceptualization of the scientific enterprise is its strict methodological prescriptions. According to a philosophy of science dominant through the 1960s, known as logical positivist empiricism, the primary test of truth is the replicability of experimental findings. Hiskes and Hiskes (1986:10-11) write that logical positivist empiricism assumes that:

1. Data obtained through careful experiment and observation are objective;

2. There is one universally valid logic for science; and

3. Through rigorous application of logic to data, science gradually makes progress toward the ancient Greek ideal of theoria.

According to the logical positivist empiricist view, data are incontrovertible and unchanging. The observations of any two rational persons witnessing the same event would be identical. Data accumulated through the repetition of similar events eventually leads to the development of theory that integrates abstract concepts and generalizable principles to explain diverse phenomena. Logic is linear and one-directional. In short, this view implies that the products of work undertaken through the scientific method are absolute and without ambiguity.

The characterization of science as a dispassionate activity, (that is, one that is not influenced by the views of the individual scientist), has deep roots. In the 16th century, Francis Bacon, a chief proponent of the modern method of scientific inquiry, sought to describe a way of accumulating knowledge about the physical world that was free of theologically-based distortion and founded on the observa- 
tion of reality rather than imagination or fancy. Moreover, to depict science in a manner that would be palatable to the then-powerful religious establishment, Bacon carefully delineated the territory of science and claimed that the science of nature "is studiously indifferent to good and evil" (Lakoff 1966:9).

This formulation of science coincided with a period in which intense disputes over critical theological and philosophical issues were disrupting English society as well as life on the European continent (Ben-David 1971). The growing popularity of the Baconian view at that time is attributable to the attractiveness of the idea that a consensus on procedure is neutral with respect to religion or politics. What later became known as the scientific method represented a way for intellectual thought to progress in England amidst the havoc of the country's civil revolution (Ben-David 1971).

In more recent years, scientists and their spokespersons have aggressively fought to reaffirm and protect the image of a neutral science. Proponents of unconditional financial support for scientific research by the federal government have argued that the scientific community is, and ought to be allowed to remain, self-monitoring and autonomous. The scientific community has been called a priesthood, an estate, and a republic (Lapp 1965; Polanyi 1972; Price 1965) and scientists, accordingly, have been described as objective, disinterested, uncorruptible, and impartial (Wood 1964). Uniform standards of validating fact and the self-imposed discipline of the scientific method are offered as guarantees that science is a depersonalized and selfless quest for truth.

\section{FOUR ROLES FOR SCIENCE}

If scientific work is viewed as completely outside the social and political bickering and battling that occurs among individuals and groups in society, then a powerful role for science in environmental conflict would be nearly unassailable. Based on the assumption that the scientific method does indeed ensure the political neutrality of knowledge thereby produced, stakeholders in environmental conflict have crafted four important roles for science. These are the roles of science as discoverer, mechanism of accountability, shield, and tool of persuasion.

\section{Science As Discover}

The role for science most easily associated with an idealized conceptualization of the scientific method is the role of discoverer. In this role, a scientist working in relative isolation from contemporary social and political skirmishes incidentally uncovers a condition the researcher, from her own personal value framework, deems worthy of wider discussion or public action. When Oregon State University student Eric Forsman chanced upon a spotted owl in the Pacific northwest in 1968 , he had no intention that this and subsequent encounters would fuel a debate between protecting an endangered species or an endangered livelihood twenty years later. Rowland and Molina's discovery of the correlation between CFCs and the ozone hole over Antarctica was similarly not inspired by an ambition to change public policy. However, each event contributed significantly to the 
debates over logging in the Northwest and reductions in the use of ozone-depleting gases, respectively.

In most cases, science plays the role of discoverer or educator only at the earliest stages of, or even prior to, conflict development. The role of science as discoverer reflects an idealized image of a scientist's quest to understand conditions in the physical world. One need not look very far, however, to recognize the critical effect that the researcher's personal value framework has on how that researcher interprets new information. Although biologists working for large timber companies would be unlikely to experience the same intimate moments of solitude with the forest as Forsman, had spotted owls crossed their paths in the late 1960s, it is doubtful that their responses would have been the same as his. Rare wildlife species simply are not a high priority for timber company employees.

\section{Science as a Mechanism of Accountability}

A second role for science might best be understood by looking back a half century to the New Deal period when Franklin D. Roosevelt established a number of independent government agencies like the Tennessee Valley Authority. These independent, specialized agencies were built on the assumption that certain types of decisions ought to (and could) be based on technical expertise, not politics. Congress reacted swiftly to try to ensure that decisions by such agencies were in fact based on non-partisan expertise and not politics by enacting the Administrative Procedures Act (APA) in 1946. The APA stipulates procedures for agency decision making, which essentially prescribes that agencies keep a record of their decision-making process and that decisions are consistent with a reading of that record. As agency decisions became more technical in nature (as with the regulation of new technologies and control of air and water pollution) and as new legislation awarded legal standing to citizen groups to challenge agency decisions, decision makers paid increasing attention to technical and scientific studies relevant to their decisions.

Since the 1970s, more than twenty new administrative agencies have been created, most having to do with environmental and health and safety regulation. Corresponding legislation have reinforced the need for decision makers to provide explicit technical documentation to support policy decisions. Statutes, such as the Occupational Safety and Health Act (OSHA), the Toxic Substances Control Act (TSCA), and Resource Conservation and Reclamation Act (RCRA) make explicit reference to the technical basis for decisions. Finally, judges have conceived their role as ensuring that agency decisions are reasonably consistent:

[The] court has a supervisory function of review of agency decisions. This begins with enforcing the requirement of reasonable procedure, fair notice, and opportunity for the parties to present their case, and it includes examining the evidence and fact findings to see both that the evidentiary fact findings are supported by the record and that they provide a rational basis for inferences of ultimate fact (Levanthal 1974:511).

Although decision making without the benefit of technical expertise in areas such as environmental policy would be foolhardy, a primary goal of these decision- 
making prescriptions was accountability. As long as agency decision makers were constrained by the technical experts' interpretations of the physical conditions and alternative actions, Congress assumed that raw politics would be constrained.

\section{Science as a Shield}

Astute decision makers quickly recognized that by framing decisions around boundaries drawn by technical studies, they could build a rationale that would protect them from the political fallout of publicly unpopular decisions. By presenting such information as definitive with respect to policy decisions, the decision maker attempts to create the illusion that science is arbitrating between multiple policy viewpoints or decision alternatives. For example, a decision maker may claim that because certain soil hydrologists have agreed that a particular tract of land proposed for development meet criteria defining a wetland, a development permit must be denied. In effect, the decision maker is claiming that the scientific findings (i.e., the determination that the land is a wetland) preclude a decision to allow development and thus absolve him of responsibility and shield him from the wrath of unhappy constituents. As one writer noted with regard to Congressional deliberations regarding policies for protecting health and the environment, "turning the job of defining adequate standards over to the 'experts' relieves Congressmen [sic] of the burden of resolving difficult controversies" (Melnick 1983:251).

The political expediency of this tactic is obvious, but the logic is questionable. In practice, the decision-maker exercises considerable discretion in formulating a response to scientific reports. He may accept the findings and rule otherwise (for other specified reasons, such as economic hardship, for example), he may seek additional advice, or he may order additional study. Throughout his term in office, Ronald Reagan avoided dealing with the acid rain issue raised by groups in the northeastern United States and Canada. Rather than heeding experts who believed the available evidence indicated a causal relationships between smokestack emissions from the industrial mid-West and rising acidity levels and ailing forests further north, Reagan preferred to listen to those scientists who cautiously avoided affirming a connection. Deciding to adopt the decision alternative suggested by a scientific finding or to wait for further confirmation is a political act.

\section{Science as a Tool of Persuasion}

Once science is recognized as a source of authority for justifying decisions, it is a small step to see its power in persuading the polity of the legitimacy of one policy or decision alternative over others (Dickson 1984; Nelkin and Pollack 1981). Like religion and the rule of the monarchy prior to the Age of Enlightenment, science is used in twentieth century decision making as a primary source of legitimacy to gain political support:

By invoking the authoritative canons of scientific reasoning and method, public authorities and others having a stake in technical issues seek to demonstrate the rationality of their position and thereby gain political support and acceptance (Brickman 1984:108). 
In this role, science can be used either to support advocated positions in environmental conflicts or "to prevent policy being made around a rival scientific conclusion" (Collingridge and Reeve 1986). Opponents of a proposal might attempt to prevent a decision by either presenting alternative scientific data or analysis or by questioning the assumptions or interpretations of scientific reports that support the proposal. One well-known example of this strategic use of science in regulatory decision making is the tobacco industry's effort to stall restrictions on cigarette smoking by attempting to discredit studies linking cigarette smoking to lung cancer. In nearly any environmental conflict today, participants routinely raise questions about the assumptions, data, and models used in analyses that support opposing viewpoints.

If science and politics are separate, the boundary between science and policy is blurry at best. Science can play the role of discoverer only at very early stages of an environmental conflict, to flag a concern for action. But how that concern is framed and whether it is acted upon is a political decision. Science as a mechanism of accountability similarly serves to moderate the abuse of delegated decision-making authority, but by no means eliminates administrative discretion.

Casting science in the role of a tool of persuasion or a shield is a politically motivated act on the part of the user (policy actor) to capitalize on the authority of science derived from its image as politically neutral. However, as quickly as one set of policy advocates attempt to appropriate science to support their preferred policy or decision alternative, opposition groups move to undermine their position by discrediting the scientific basis of that position. The politics that are imbedded in science are readily uncloaked.

\section{SOCIAL CONSTRUCTIONISM AND SCIENTIFIC UNCERTAINTY}

If scientific work was indeed as free of the idiosyncracies of the investigator as the ideal described earlier would suggest, environmental conflict would not end, but the scope of the disputes would be narrowed considerably with each additional contribution from scientists with relevant expertise. Disputes would revolve around what to do in response to a given situation, not around defining the conditions themselves. For example, if EPA knew absolutely that dioxin in concentrations below a given amount would not endanger marine life directly or indirectly, debate over the dredging of the New Jersey harbor might be narrowed to a discussion of dumping method, location, or timing.

However, much in the literature of the social studies of science suggests that scientific work is not free of political content. Irrespective of the rigidities of the scientific method, a multitude of discretionary judgments are made during the course of a scientific investigation by the researcher. Thomas Kuhn describes the progression of scientific inquiry as a temporally bound consensus among scientists. According to Kuhn, researchers perceive curves in the distribution of data points on a graph in patterns that fit pre-existing theory (Kuhn 1982). While researchers have identified discretionary judgments in laboratory research (Latour 1979), the predictive sciences relied on for illuminating conditions in environmental conflicts are fraught with even higher levels of discretion (Bacow 1980). For example, in predicting the potential impacts of the construction of a 
road through a forest, wildlife biologists would need to make assumptions about a seemingly endless list of items, including the geographic boundaries of the study area, the species to be studies, conditions in surrounding wooded lands, the migration patterns of animals under changed conditions, and the level of environmental devastation occurring during the road building period itself from the intrusion of heavy construction equipment. While these assumptions and others like them are to some extent constrained by conventions of practice, many cases are sufficiently unique to make such cross-references arguably uninformative.

The choice of assumptions, boundaries, and definitions of variables are replete with methodological uncertainties and indeterminacy (Klapp 1992; Wynne 1992). For example, the selection of a model to simulate meteorological conditions predicting air pollution plumes cannot be determined through any kind of scientific exercise, but is ultimately a judgment based on the researchers' assessment of the similarities between model parameters and real life conditions or the match between available data and the variables used in the model.

Wynne (1992) has further differentiated methodological uncertainty. He identifies ignorance as contributing to uncertainty in scientific analysis. Simply, scientists are unable to account for factors of which they are unaware. In contrast to the popular belief that scientific knowledge and method recognize and attempt to reduce uncertainties, Wynne (1992:115) argues:

It is more accurate to say that scientific knowledge gives prominence to a restricted agenda of defined uncertainties-ones that are tractable-leaving invisible a range of other uncertainties, especially about the boundary conditions of applicability of the existing framework of knowledge to new situations (emphasis in original).

Another type of uncertainty encountered in science has been described as statistical uncertainty. In theory, statistical uncertainty can be eventually reduced as more and more data are accumulated. However, in practice, decisions are made long before sufficient data are obtained.

Dealing with uncertainty requires a judgment on the part of researchers in the course of their work. How one selects methodologies, models, measuring devices, indeed even one's choice of scientific theory, is seldom rigidly defined by current practice. These discretionary elements are influenced by social and political factors such as the individual's institutional affiliations, source of research funds, and disciplinary training (Knorr-Cetina 1982). Viewed in this light, scientific work carries the signature of the individual researcher and acceptance of scientific work by the scientific community more accurately represents a consensus among scientists, rather than objective fact.

\section{AN ALTERNATIVE ROLE: SCIENCE AS A TOOL OF FACILITATION}

In the highly contentious context of the 1980 s, the art of utilizing scientific argumentation for furthering political objectives flourished. The authority of science was exploited by groups on multiple sides of any given debate, prolonging decisions on particular conflicts for several years in many cases and increasing 
expenses for government, private developers and industry, and community organizations. A sentiment was developing in the academic sphere that science in the role of arbiter in environmental conflict was a misuse of scientific work. Moreover, to sustain the image of science as authoritative with respect to decisions that were inherently political is a displacement of political power from elected politicians to the hands of an elite corps of scientific experts (Dickson 1984). Reports on Ronald Reagan's heavy-handed oversight of the selection of scientists to serve on advisory committees such as the Environmental Protection Agency's Science Advisory Board made such suspicions all the more disturbing (Ashford 1984).

The question remains, can science play a role in resolving environmental conflict? Over the past decade, an alternative role for science has been emerging as a by-product of decision-making innovations that include explicit negotiations among individuals and representatives of groups engaged in an environmental dispute. In one version of environmental mediation, the scientific and technical information necessary to understand current conditions and to identify possible options for action is one of the first topics on the agenda (Carpenter and Kennedy 1988; Crowfoot and Wondolleck 1990; Susskind and Cruikshank 1987). Almost from the start, the negotiating group discusses what kind of technical knowledge is pertinent. The more particular discretionary judgments encountered in scientific and technical investigations are openly discussed and subject to agreement (Ozawa and Susskind 1985). These judgments include decisions about the kind of information needed, data collection techniques, analytical models and methodologies, how to deal with statistical and methodological uncertainty and, sometimes, the disciplinary training and institutional affiliation of the researcher. Finally, the interests and concerns of various groups with a stake in the decision are explicitly acknowledged and a period of time is set aside in the negotiations to address them. The outright recognition of competing interests serves as a signal to stakeholding groups (and the public) that such issues will be addressed in the decision-making process. With such assurance, stakeholders contending to dominate the decision process are less inclined to posture behind admittedly disputable technical argumentation, as they do in more adversarial procedures in which winning on the technical points likely means protecting their interests, and are more willing to focus on collectively accumulating and making sense of relevant data and analyses. Because the discretionary nature of assumptions is acknowledged, sensitivity analysis or the substitution of variables or values for specific variables is easily accommodated by the negotiating group, again, defusing potential disputes over technical aspects of the decision.

An early example of this approach was a 1986 rulemaking procedure conducted by the U.S. Environmental Protection Agency (EPA) (Ozawa 1991). In response to a lawsuit filed against the agency for failure to regulate carcinogenic polycyclic organic matter (POMs) under Section 112 of the Clean Air Act, the agency invited representatives from key stakeholding groups, including wood stove manufacturers, national and local environmental organizations, and various state agencies from four states to develop emission standards for wood-burning stoves, the third largest source of POMs. Operating under a strict deadline, the group successfully crafted a proposal that was supported by all participants. 
This agreement was achieved through a carefully structured procedure. At the first meeting, the group agreed to defer discussion of specific political concerns until after a solid technical basis for the rules was jointly constructed. The group labored long hours to develop this foundation of technical knowledge. Data and existing studies were collected from all known sources and closely scrutinized by technical experts from the EPA, the industry, and the environmental organizations, independently and together as a group. The discretionary nature of research assumptions and the inevitable statistical and methodological uncertainties were uncovered and debated. For example, it was widely accepted that wood stoves equipped with a catalyst emit fewer particulates than non-catalyst models, but no data existed to indicate how quickly catalysts degrade. The relative performance of catalyst-equipped stoves over the long term was thus highly uncertain. The testing performance of all models, for that matter, was disputable since emission rates vary according to basic factors such as how users stack wood and the age, type, and wetness of wood.

Discussion of assumptions regarding testing procedures, degradation rates, and countless other factors accentuated the fact that the rules were, at their core, political, not technical, products. However, this realization did not lead participants to ignore the science, as some might fear, but rather encouraged them to look more soberly at what scientific evidence existed to guide their deliberations. In some cases, the group collectively agreed that rather than thinking in terms of specific points on a scale, emission rates (or other figures) ought to be regarded as a range of plausible points.

The role of science in this regulatory negotiation comes closest to the traditional role of discoverer, described in an earlier section. Scientific knowledge was shared not simply to prove the superiority of one policy alternative over another, but to educate all participants about the status and quality of available information. Science in this regulatory negotiation went beyond the role of discoverer, however. By working together to construct a joint understanding of the technical aspects of the standard-setting task, groups with competing political interests were also learning to listen to another and to appreciate one another's talents, skills, and knowledge base. Discussing mundane issues such as the way most people stack wood or the dominant type of wood burned in particular regions of the country provided a relatively calm atmosphere conducive to dialogue. Importantly, those with specialized expertise were explicitly asked and reminded that their role was to educate, not intimidate, the group on technical issues. The meetings also provided an opportunity for informal discussions and the formation of coalitions that facilitated the exchange of interest-related information and development of a fuller understanding of and mutual respect for all legitimate claims. In this case, science provided an opportunity for participants to develop a constructive pattern of interaction.

\section{CONCLUSION}

This example suggests that an alternative role for science in environmental conflict may be crafted. However, the decision-making process must be deliberately structured to ensure the following conditions. First, access to scientific expertise and 
analysis must be open to all stakeholding parties. Second, the agenda for negotiations must clearly set aside a period for addressing explicitly political concerns in order to discourage participants from stubbornly posturing behind technical positions that they believe will afford them political gains. Finally, experts invited to participate in the decision-making process must commit to share scientific information in order to educate, not intimidate, the stakeholders. If these conditions are met, a discussion of relevant technical information can provide an opportunity for parties to gain a fuller understanding of both the technical and political dimensions of the dispute. Science can be used as a tool of facilitation. Just as science was used as a means of advancing intellectual thought in the highly contentious context of 16th century England, negotiating the scientific basis for environmental decisions may represent a way to maintain dialogue and develop a constructive understanding of the multiple perspectives of a given environmental conflict.

\section{REFERENCES}

Ashford, Nicholas. 1984. "Advisory Committees in OSHA and EPA: Their Use in Regulatory Decision- making." Science, Technology, and Social Values 9: 72-82.

Bacow, Lawrence. 1980. "The Technical and Judgmental Dimensions of Impact Assessment." Environmental Impact Assessment Review 1: 109-124.

Ben-David, Joseph. 1971. The Scientist's Role in Society. Englewood Cliffs, NJ: Prentice-Hall.

Brickman, Ronald. 1984. "Science and the Politics of Toxic Chemical Regulation: U.S. and European Contrasts." Science, Technology, and Human Values 9: 107-111.

Carpenter, Susan, and W.J.D. Kennedy. 1988. Managing Public Disputes. San Francisco, CA: Jossey-Bass.

Clean Air Act. 1967. U.S. Code 42.

Collingridge, David, and Colin Reeve. 1986. Science Speaks to Power. New York: St. Martin's Press.

Crowfoot, James E., and Julia M. Wondolleck. 1990. Environmental Disputes: Community Involvement in Conflict Resolution. Washington, DC: Island Press.

Dickson, David. 1984. The New Politics of Science. New York: Pantheon Books.

Hiskes, Anne L., and Richard P. Hiskes. 1986. Science, Technology, and Policy Decisions. Boulder, CO: Westview.

Klapp, Merrie G. 1992. Bargaining With Uncertainty: Decisionmaking in Public Health, Technological Safety, and Environmental Quality. New York: Auburn House.

Knorr-Cetina, Karin D. 1982. "Scientific Communities of Transepistemic Arenas of Research? A Critique for Quasi-Economic Models of Science." Social Studies of Science 12: 101-130.

Kuhn, Thomas. 1982. "Normal Measurement and Reasonable Judgment." Pp. 75-93 in Science in Context, edited by Barry Barnes and David Edge. Cambridge, MA: MIT Press.

Lakoff, Sanford A. (ed.). 1966. Knowledge and Power. New York: The Free Press.

Lapp, Ralph E. 1965. The New Priesthood: The Scientific Elite and the Uses of Power. New York: Harper \& Row.

Latour, Bruno. 1979. Life in the Laboratory. Beverly Hills, CA: Sage.

$\rightarrow$ Levanthal, Harold. 1974. "Environmental Decisionmaking and the Role of the Courts." University of Pennsylvania Law Review 122: 509-555.

Melnick, R. Shep. 1983. Regulation and the Courts: The Case of the Clean Air Act. Washington, DC: The Brookings Institution.

Nelkin, Dorothy, and Michael Pollack. 1981. The Atom Beseiged. Cambridge, MA: MIT Press.

Ozawa, Connie P. 1991. Recasting Science: Consensual Procedures in Public Policy Making. Boulder, CO: Westview.

Ozawa, Connie P., and Lawrence E. Susskind. 1985. "Mediating Science-Intensive Policy Disputes." Journal of Policy Analysis and Management 5: 23-39.

$\rightarrow$ Polanyi, Michael. 1972. "The Republic of Science: Its Political and Economic Theory." Minerva 1: 54-73.

Price, Don K. 1965. The Scientific Estate. Cambridge, MA: The Belknap Press of Harvard University. 
Strum, Charles. 1993. "Dredging Stays Mired in a Debate Over Dioxin." The New York Times, Section B, p. 1.

Susskind, Lawrence, and Jeffrey Cruikshank. 1987. Breaking the Impasse: Consensual Approaches to Resolving Public Disputes. New York: Basic Books.

Wood, Robert C. 1964. "Scientists and Politics: The Rise of an Apolitical Elite." Pp. 41-72 in Scientists and National Policy-Making, edited by Robert Gilpin and Christopher Wright. New York: Columbia University Press.

$\rightarrow$ Wynne, Brian. 1992. "Uncertainty and Environmental Learning: Reconceiving Science and Policy in the Preventive Paradigm." Global Environmental Change 2: 111-127. 